\title{
Time Scale Changes in the Water Quality of the Ganga River, India and Estimation of Suitability for Exotic and Hardy Fishes
}

Tiwari A, Dwivedi AC* and Mayank P

Regional Centre, ICAR - Central Inland Fisheries Research Institute, Allahabad, Uttar Pradesh, India

\begin{abstract}
The water quality of rivers is an issue of serious concern today. Rivers are heavily impacted due to their use for carrying off the industrial, municipal, agricultural and domestic effluents. Water samples were collected for the present study from the Ganga River at Kanpur, Allahabad and Varanasi sites, during the period $2011-2012$. The minimum temperature $\left(17^{\circ} \mathrm{C}\right)$ was recorded in winter season. The $\mathrm{pH}$, TDS, EC, sulphate, phosphate, nitrate, BOD and COD values exhibited their minimum at Allahabad site. The chloride and dissolved oxygen were recorded minimum at Kanpur site while alkalinity and total hardness had their lowest values at Varanasi site. The water quality of the Kanpur site was very poor compared to Varanasi and Allahabad sites. However, the Ganga river waters could host some tolerant fish species such as the exotic Cyprinus carpio and Oreochromis niloticus and also catfishes. All these species are very hardy, in respect of poor water quality, thus they (exotic species) have powerfully invaded in degraded systems worldwide.
\end{abstract}

Keywords: Ganga River; Water quality; Pollution; Environmental condition; Tolerant fish species

\section{Introduction}

The Ganga river quality is day by day deceased due to domestic and industrial influent. The Ganga River is a backbone of Indian biodiversity (aquatic flora and fauna). Pollution threatens not only humans, but also more than 130 fish species, 83 amphibian species and the endangered Ganga river dolphin. But, current time poor water quality of the Ganga River provides shelter to some exotic aquatic organisms.

The contamination of fresh waters through ample variety of pollutants has become a matter of great concern over the last two decades especially inland water [1-5]. The contamination level in the water bodies is changes according to season and. The concentrations of pollutants in water samples only indicate the condition at the time of sampling. Due to industrialization, the number of factories and population has increased rapidly. The riverine systems may be greatly infected with pollutants released from industrial, domestic, mining and agricultural effluents [6-8]. Discharge of pollutants into rivers or any aquatic environment can change aquatic species diversity, abundance and ecosystems, due to their toxicity and accumulative behavior [9-13]. Over the last two decades huge scale usage of chemicals in various human activities has grown very rapidly. In developing and underdeveloped countries, the industrial and domestic effluents are release directly or indirectly into the large water bodies $[14,15]$.

Catfishes such as Sperata aor, S. seenghala, Wallago attu, Rita rita, Clupisoma garua, Eutropiichthys vacha and two exotics fish species Common carp (Cyprinus carpio) and Tilapia (Oreochromis niloticus) are commercially exploited with highly contribution in the landing of the Ganga river. Common carp (Cyprinus carpio) and Tilapia (Oreochromis niloticus) are exotic/alien fish species for India. Both species are of great economic importance in the country [16-18], and are commercially exploited in the Ganga River (at Kanpur to Varanasi section) and its tributaries [13,19-21]. Fishes are widely used to evaluate the health of aquatic ecosystems because pollutants are building up in the food chain and are responsible for adverse effects and death in the aquatic systems.

Water pollution of rivers in India has now been reaching to a point of predicament due to unplanned urbanization and rapid growth of industrialization. Various fragmented studies concerning the water quality of Ganga River are available, but complete middle stretch data are not available which is most important for fisheries and human life.
Record and assessment of the present research work is necessary to formulate up to date decisions about management of the river habitat and fishery to help of restoration and conservation of flora and fauna.

\section{Materials and Methods}

The River Ganga is the most important river system in India. It originates from the Gangotri glacier at Gomukh, at an altitude of about $6000 \mathrm{~m}$ in the Garhwal Himalaya. The Ganga river is about $2525 \mathrm{~km}$ long, covering a basin area of $861,404 \mathrm{~km}^{2}$. The Ganga river system drains about one fourth of the Indian subcontinent. The river supports abundant biological wealth, characterized by its rich fisheries and faunal diversity.

\section{Collection of samples}

Water samples were collected from all the selected sites (Kanpur, Allahabad and Varanasi) during January 2011 to December 2012 from the Ganga River, India (Figure 1). During the entire study period of one year, samples were collected three times in a year: during winter, summer and monsoon seasons. The sampling was done between 9.30 to $11.00 \mathrm{AM}$.

\section{Water sampling procedures}

For physico-chemical analysis, surface water samples were collected from each selected site in $500 \mathrm{ml}$ polyethylene bottles fitted with polyethylene caps. For dissolved oxygen analysis, samples were fixed with manganese sulphate and alkaline iodide in $250 \mathrm{ml} \mathrm{BOD}$ bottles in the field. For the analysis of heavy metals, $500 \mathrm{ml}$ of water sample was taken from each site and was immediately acidified with 10 $\mathrm{ml}$ of $6 \mathrm{~N} \mathrm{HNO}_{3}$. All samples were brought to the laboratory. Acidified samples were stored at $4^{\circ} \mathrm{C}$ in the refrigerator for further analysis.

*Corresponding author: Dwivedi AC, Regional Centre, ICAR - Central Inland Fisheries Research Institute, 24 Panna Lal Road, Allahabad-211 002, Uttar Pradesh, India, Tel: +919450211911; E-mail: saajjjan@rediffmail.com

Received May 31, 2016; Accepted August 08, 2016; Published August 08, 2016

Citation: Tiwari A, Dwivedi AC, Mayank P (2016) Time Scale Changes in the Water Quality of the Ganga River, India and Estimation of Suitability for Exotic and Hardy Fishes. Hydrol Current Res 7: 254. doi:10.4172/2157-7587.1000254

Copyright: ( 2016 Tiwari A, et al. This is an open-access article distributed under the terms of the Creative Commons Attribution License, which permits unrestricted use, distribution, and reproduction in any medium, provided the original author and source are credited. 

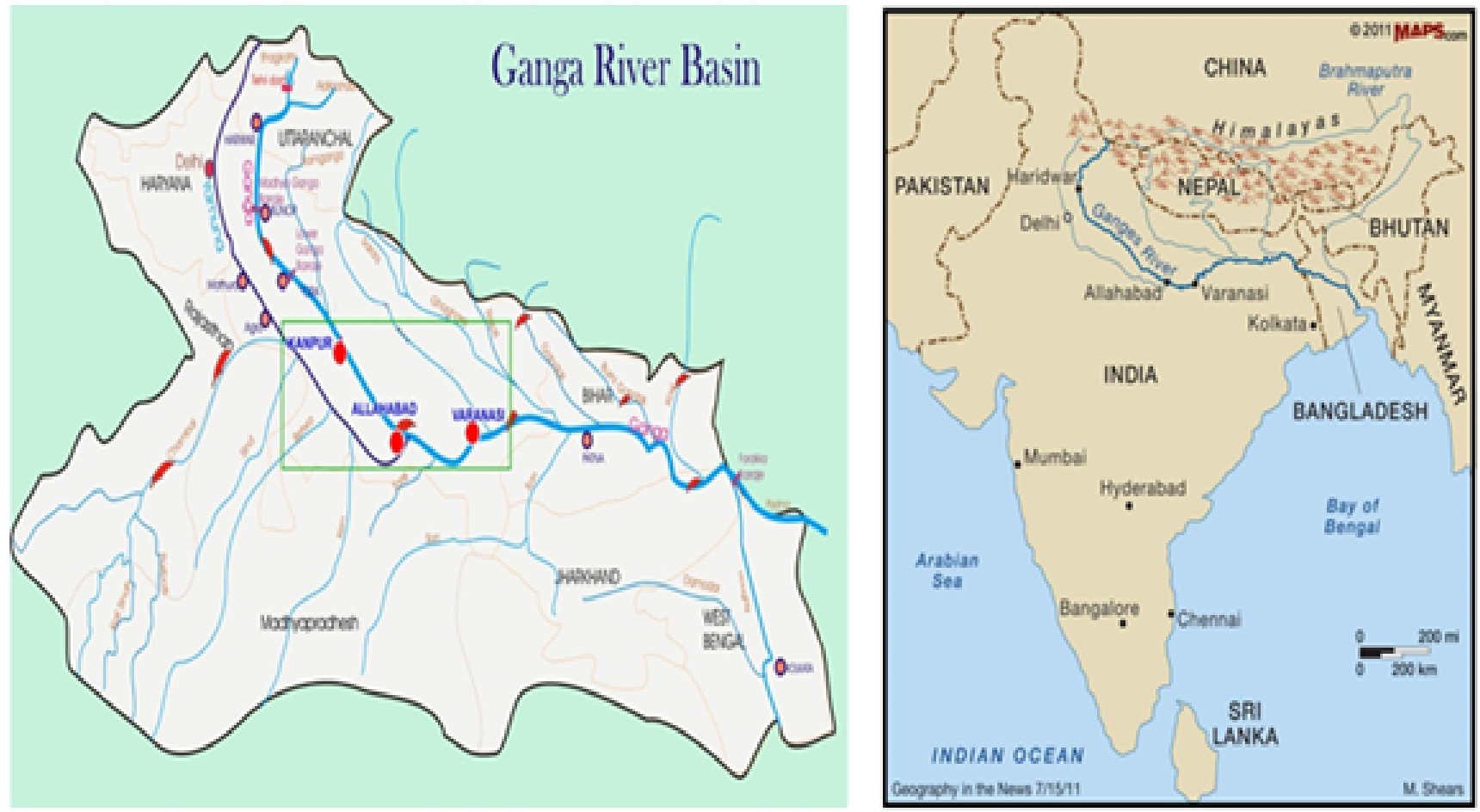

Figure 1: Study area responding the Ganga River, shows selected sites.

\section{Analysis of physico-chemical parameters of water sample}

For the analysis of physio-chemical properties of river water, specialised sampling and sample handling procedure are required. The water samples were analysed for various parameters in the laboratory of Botany Deportment, University of Allahabad, Allahabad, India. Various physio-chemical parameters like Temperature, $\mathrm{pH}$, Total Dissolved Solid (TDS), Electrical Conductivity (EC), Total Hardness (TH), Sulphate, Phosphate, Alkalinity, Nitrate, Chloride, Dissolved oxygen, Biological Oxygen Demand (BOD) and Chemical Oxygen Demand (COD) have been analysed [22].

\section{Temperature}

Temperature was measured by Multi probe ITS-701.

\section{pH}

It was measured by Multi probes ITS -701 direct at the sampling site.

\section{Total Dissolved Solid (TDS)}

It was measured by Multi Parameter ITS-701 direct at the sampling site at the time of sample collection and expressed in $\mathrm{mg} / \mathrm{l}$.

\section{Electrical Conductivity (EC)}

The electricity conductivity is a measurement of capability of water to transmit electricity in a water bodies. It was measured by using Multi Parameter ITS-701 direct at the sampling site at the time of sample collection. It expressed in $\mathrm{mhos} / \mathrm{cm}$.

\section{Sulphates}

It was measured by nephelometric method in which the concentration of turbidity is measured against the known concentration of synthetically prepared sulphate solution. Sulphate was measured by Perkin Elmer UV/ VIS spectrophotometer model Lambda 25. It expressed in $\mathrm{mg} / \mathrm{l}$.

\section{Phosphates}

Phosphates were measured by Perkin Elmer UV/VIS spectrophotometer model Lambda 25. Concentrations were expressed in $\mathrm{mg} / \mathrm{l}$.

\section{Alkalinity}

Alkalinity was measured by Multi parameter ITS-701 direct at the sampling site the time of sample collection and expressed in $\mathrm{mg} / \mathrm{l}$.

\section{Chlorides}

Chlorine was measured by chlorine meter model it's 1001 directly at the sampling site at the time of sample collection and expressed in $\mathrm{mg} / \mathrm{l}$.

\section{Total Hardness}

Total Hardness was measured by Multi Parameter ITS -701 direct at the sampling site at the time of sample collection and expressed in $\mathrm{mg} / \mathrm{l}$.

\section{Nitrates}

They were measured in a Perkin Elmer UV/VIS spectrophotometer model Lambda 25. Concentrations were expressed in $\mathrm{mg} / \mathrm{l}$.

\section{Dissolved Oxygen (DO)}

It was measured by using Multi Parameter ITS-701 direct at the sampling site at the time sample collection and expressed in $\mathrm{mg} / \mathrm{l}$.

\section{Biochemical Oxygen Demand (BOD)}

It was measured by automated oxygen analyser. It expressed inmg/l.

\section{Chemical Oxygen Demand (COD)}

An automatic analyser was used to measure the COD level 
in all sample collected from different rivers at various sites. It is expressed in $\mathrm{mg} / \mathrm{l}$.

\section{Results and Discussion}

\section{Temperature}

At Kanpur site, the average temperature was $21.67 \pm 5.69^{\circ} \mathrm{C}$. The minimum temperature has been recorded in winter $\left(17^{\circ} \mathrm{C}\right)$ while the maximum in the summer season $28^{\circ} \mathrm{C}$ (Table 1). At Allahabad site, the lowest temperature was recorded in the winter $\left(17^{\circ} \mathrm{C}\right)$, modest increase was noted in monsoon season $\left(22^{\circ} \mathrm{C}\right)$ and the highest was noted in

\begin{tabular}{|c|c|c|c|c|}
\hline Parameters & Summer & Monsoon & Winter & Mean \pm SD \\
\hline Temperature $\left({ }^{\circ} \mathrm{C}\right)$ & 28 & 20 & 17 & $21.67 \pm 5.69$ \\
\hline $\mathrm{pH}$ & 8.8 & 8.2 & 8.5 & $8.50 \pm 0.30$ \\
\hline Total Dissolved Solid $(\mathrm{mg} / \mathrm{l})$ & 412 & 540 & 258 & $403.33 \pm 141.20$ \\
\hline Electrical Conductivity $(\mathrm{mhos} / \mathrm{cm})$ & 628 & 378 & 532 & $512.67 \pm 126.12$ \\
\hline Sulphate $\mathrm{SO}_{4}^{-}(\mathrm{mg} / \mathrm{l})$ & 55 & 104 & 48 & $69.00 \pm 30.51$ \\
\hline${\text { Phosphate } \mathrm{PO}_{4}^{-}(\mathrm{mg} / \mathrm{l})}^{-1}$ & 1.58 & 0.66 & 0.82 & $1.02 \pm 0.49$ \\
\hline Alkalinity $(\mathrm{mg} / \mathrm{l})$ & 123 & 182 & 264 & $189.67 \pm 70.81$ \\
\hline Chloride $\mathrm{Cl}(\mathrm{mg} / \mathrm{l})$ & 32 & 15 & 27 & $24.67 \pm 8.74$ \\
\hline Total Hardness $(\mathrm{mg} / \mathrm{l})$ & 174 & 110 & 240 & $174.67 \pm 65$ \\
\hline Nitrate $(\mathrm{mg} / \mathrm{l})$ & 1.7 & 0.45 & 0.94 & $1.03 \pm 0.63$ \\
\hline Dissolved Oxygen $(\mathrm{mg} / \mathrm{l})$ & 4 & 3 & 4.8 & $3.93 \pm 0.90$ \\
\hline Biological Oxygen Demand $(\mathrm{mg} / \mathrm{l})$ & 36 & 48 & 32 & $38.67 \pm 8.33$ \\
\hline Chemical Oxygen Demand $(\mathrm{mg} / \mathrm{l})$ & 22 & 38 & 29 & $29.67 \pm 8.02$ \\
\hline
\end{tabular}

Table 1: Analysis of Physico-chemical properties from Ganga River water at Kanpur.

\begin{tabular}{|c|c|c|c|c|}
\hline Parameters & Summer & Monsoon & Winter & Mean \pm SD \\
\hline Temperature $\left({ }^{\circ} \mathrm{C}\right)$ & 27 & 22 & 17 & $22.00 \pm 5$ \\
\hline $\mathrm{pH}$ & 8.2 & 7.6 & 7.9 & $7.90 \pm 0.30$ \\
\hline Total Dissolved Solid $(\mathrm{mg} / \mathrm{l})$ & 406 & 536 & 254 & $398.67 \pm 141.14$ \\
\hline Electrical Conductivity $(\mathrm{mhos} / \mathrm{cm})$ & 612 & 375 & 528 & $505.00 \pm 120.16$ \\
\hline Sulphate $\mathrm{SO}_{4}^{-}(\mathrm{mg} / \mathrm{l})$ & 46 & 68 & 38 & $50.67 \pm 15.53$ \\
\hline${\text { Phosphate } \mathrm{PO}_{4}^{-}(\mathrm{mg} / \mathrm{l})}^{-}$ & 1.5 & 0.63 & 0.78 & $0.97 \pm 0.47$ \\
\hline Alkalinity $(\mathrm{mg} / \mathrm{l})$ & 120 & 178 & 261 & $186.3 \pm 9.70$ \\
\hline Chloride $\mathrm{Cl}(\mathrm{mg} / \mathrm{l})$ & 33 & 20 & 27 & $26.6 \pm 8.51$ \\
\hline Total Hardness $(\mathrm{mg} / \mathrm{l})$ & 170 & 107 & 235 & $170.67 \pm 7.56$ \\
\hline Nitrate $(\mathrm{mg} / \mathrm{l})$ & 1.5 & 1.4 & 0.23 & $1.04 \pm 0.71$ \\
\hline Dissolved Oxygen $(\mathrm{mg} / \mathrm{l})$ & 5 & 4 & 6 & $5.00 \pm 1$ \\
\hline Biological Oxygen Demand $(\mathrm{mg} / \mathrm{l})$ & 36 & 44 & 22 & $34.00 \pm 11.14$ \\
\hline Chemical Oxygen Demand $(\mathrm{mg} / \mathrm{l})$ & 19 & 28 & 23 & $23.33 \pm 4.51$ \\
\hline
\end{tabular}

Table 2: Analysis of Physico-chemical properties from Ganga River water at Allahabad.

\begin{tabular}{|c|c|c|c|c|}
\hline Parameters & Summer & Monsoon & Winter & Mean \pm SD \\
\hline Temperature $\left({ }^{\circ} \mathrm{C}\right)$ & 27 & 25 & 20 & $24.00 \pm 3.61$ \\
\hline $\mathrm{pH}$ & 8.2 & 7.7 & 8.0 & $7.97 \pm 0.25$ \\
\hline Total Dissolved Solid $(\mathrm{mg} / \mathrm{l})$ & 406 & 425 & 385 & $405.33 \pm 20.01$ \\
\hline Electrical Conductivity $(\mathrm{mhos} / \mathrm{cm})$ & 695 & 640 & 688 & $674.33 \pm 29.94$ \\
\hline Sulphate $\mathrm{SO}_{4}^{-}(\mathrm{mg} / \mathrm{l})$ & 43 & 57 & 36 & $45.33 \pm 10.69$ \\
\hline${\text { Phosphate } \mathrm{PO}_{4}^{-}(\mathrm{mg} / \mathrm{l})}^{-1.42}$ & 1.42 & 1.11 & 1.37 & $1.30 \pm 0.17$ \\
\hline Alkalinity $(\mathrm{mg} / \mathrm{l})$ & 107 & 139 & 172 & $139.3 \pm 32.50$ \\
\hline Chloride $\mathrm{Cl}(\mathrm{mg} / \mathrm{l})$ & 49 & 45 & 43 & $45.67 \pm 3.06$ \\
\hline Total Hardness $(\mathrm{mg} / \mathrm{l})$ & 134 & 95 & 211 & $146.67 \pm 59.03$ \\
\hline Nitrate $(\mathrm{mg} / \mathrm{l})$ & 2.6 & 2.4 & 2.1 & $2.37 \pm 0.25$ \\
\hline Dissolved Oxygen $(\mathrm{mg} / \mathrm{l})$ & 4 & 3.3 & 5 & $4.17 \pm 0.76$ \\
\hline Biological Oxygen Demand $(\mathrm{mg} / \mathrm{l})$ & 30 & 38 & 25 & $31.00 \pm 6.56$ \\
\hline Chemical Oxygen Demand $(\mathrm{mg} / \mathrm{l})$ & 21 & 36 & 26 & $27.67 \pm 7.64$ \\
\hline
\end{tabular}

Table 3: Analysis of Physico-chemical properties from Ganga River water at Varanasi. summer season $\left(27^{\circ} \mathrm{C}\right.$ ). The average temperature was $22.0 \pm 5^{\circ} \mathrm{C}$ (Table 2). At Varanasi site, the average temperature was $24.00 \pm 3.61^{\circ} \mathrm{C}$. The minimum temperature of $20^{\circ} \mathrm{C}$ was recorded in winter; moderately increased was noted in monsoon season $\left(25^{\circ} \mathrm{C}\right)$ and the maximum temperature in summer $\left(27^{\circ} \mathrm{C}\right)$ (Table 3$)$. The mean temperature of the Ganga River is most suitable for C. carpio and O. niloticus for breeding and growth $[15,16,19]$. The present environmental conditions of the Ganga river are most suitable for breeding of both fishes for two or three times in a year $[15,19]$. Praveen [23] reported that temperature at Kanpur ranged from $21^{\circ} \mathrm{C}$ to $30^{\circ} \mathrm{C}$ and $14^{\circ} \mathrm{C}$ to $32^{\circ} \mathrm{C}$ by Trivedi [24]. According to Raghuvanshi [25] temperature was varied from $24.2^{\circ} \mathrm{C}$ to $32.5^{\circ} \mathrm{C}$ from the Ganga River at Allahabad. Zafer [26] reported monsoon season temperature varied from $25.8^{\circ} \mathrm{C}$ to $26.1^{\circ} \mathrm{C}$ in 2002 and 2003 which was higher than present study. Singh [27] observed that temperature ranged from $22.1 \pm 1.3^{\circ} \mathrm{C}$ to $33.8 \pm 1.4^{\circ} \mathrm{C}$ at Rajghat (Varanasi) which was slightly higher than present finding. Thareja [28] recorded that the temperature ranged from $16^{\circ} \mathrm{C}$ to $30^{\circ} \mathrm{C}$ in Kanpur site from the Ganga river. Temperature is one of the important aspects in the aquatic ecosystem as it plays a key role in determination of other parameters such as conductivity, saturation stage of gases and different forms of alkalinity $[29,30]$.

\section{pH}

The average $\mathrm{pH}$ values were $8.50 \pm 0.30,7.90 \pm 0.30$ and $7.97 \pm 0.25$ at Kanpur, Allahabad and Varanasi sites, respectively (Tables 1-3). The lowest $\mathrm{pH}$ was recorded at Allahabad site (7.6, Table 2). It has been observed that $\mathrm{pH}$ is generally higher in summer than other season. Maximum values of $\mathrm{pH}$ during summer may be due to increased photosynthesis of the algal bloom resulting into the precipitation of carbonates of calcium and magnesium from bicarbonates (Prakash et al.). The $\mathrm{pH}$ of different aquatic ecosystems determines the health and biological characteristics of those systems. The $\mathrm{pH}$ value of the Ganga river water falls between slightly acidic to moderately alkaline and has relationship with the solubility and accumulation of heavy metal in river water as well as sediment. The $\mathrm{pH}$ is not limiting factor for C. carpio and O. niloticus in the Ganga River and its tributaries, India. Tripathi [31] reported lower mean value of $\mathrm{pH} 7.60 \pm 0.30$ at Varanasi compared to present finding in all sampling sites while Rai [32] observed 7.2 \pm 0.1 to $7.9 \pm 0.1$ at the same site in the year 2005. Rai [33] reported average value of $\mathrm{pH} 7.80$ from lower stretch of the Ganga River at Kolkata. Gupta [34] observed pH values between 7.3-7.7 in Yamuna river water at Agra.

\section{Total Dissolved Solid (TDS)}

At Kanpur site, the average TDS recorded was $403.33 \pm 141.20$ $\mathrm{mg} / \mathrm{l}$. The minimum TDS $258 \mathrm{mg} / \mathrm{l}$ was recorded in the winter season, while as the maximum TDS in the monsoon $540 \mathrm{mg} / \mathrm{l}$ with moderately decreased $412 \mathrm{mg} / \mathrm{l}$ in summer season (Table 1). At Allahabad site, the minimum TDS was recorded $254 \mathrm{mg} / \mathrm{l}$ in the winter season, moderately increased in summer season which was $406 \mathrm{mg} / \mathrm{l}$ and the maximum $536 \mathrm{mg} / \mathrm{l}$ in monsoon season. The average TDS was noted $398.67 \pm$ 141.14. At Varanasi site, the average TDS was observed $405.33 \pm 20.01$ (Figure 2). The minimum TDS $385 \mathrm{mg} / \mathrm{l}$ was noted in the winter season, moderately increased $406 \mathrm{mg} / \mathrm{l}$ in summer season and the maximum $425 \mathrm{mg} / \mathrm{l}$ in monsoon season. A high content of dissolved solid element affect the density of water influence osmoregulation of fresh water in organism, reduce solubility of gases and utility, of water for drinking. The TDS is not limiting factor for C. carpio and O. niloticus in the Ganga River, India. After invasion of $C$. carpio in the Ganga River TDS was increased [15]. Its browsing nature increased suspended solids in the Ganga River [16]. According to Vilizzi [35] a considerably found in 


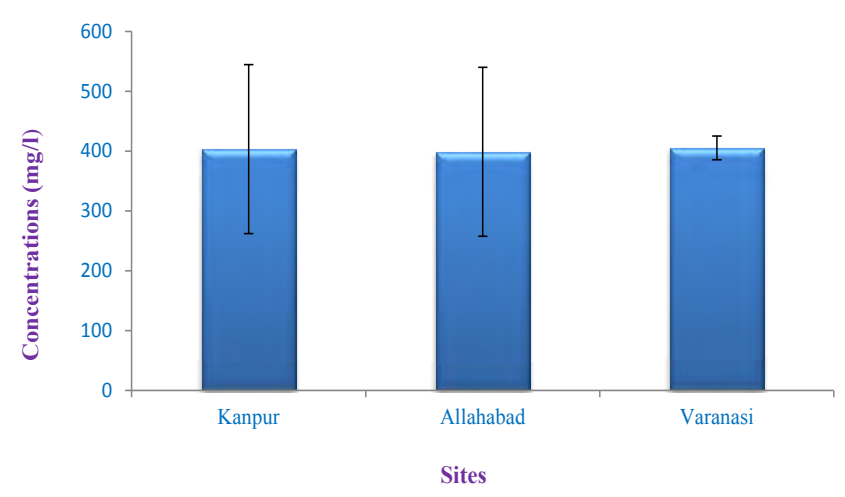

Figure 2: Site variation in TDS from the Ganga River, India.

various water bodies, to increase nitrogen, turbidity/suspended solids, phosphorus and phytoplankton or chlorophyll (about 66-87) in the water bodies due to C. carpio. Maheshwari [36] recorded that the TDS value varied from 178 to $200 \mathrm{mg} / \mathrm{l}$ in summer season from the Yamuna River at Agra, India. Khwaja [37] observed mean TDS values $152 \pm$ 11 in summer and $725 \pm 16 \mathrm{mg} / \mathrm{l}$ in winter at Kanpur from the Ganga River. Katiyar [38] reports TDS mean values $381.37 \pm 70.39 \mathrm{mg} / \mathrm{l}$ in summer, $417.25 \pm 4.33 \mathrm{mg} / \mathrm{l}$ in monsoon which are higher than present findings and $371.25 \pm 14.22 \mathrm{mg} / \mathrm{l}$ in winter season at Jajmau, Kanpur which are lower than present finding.

\section{Electrical Conductivity (EC)}

Chemically pure water does not conduct electricity. Any rise in the electrical conductivity of water indicates pollution. The maximum EC was noted in summer season $628 \mu \mathrm{mho} / \mathrm{cm}$ while as the minimum 378 $\mu \mathrm{mho} / \mathrm{cm}$ in the monsoon season with the moderately increased 532 $\mu \mathrm{mho} / \mathrm{cm}$ in winter season at Kanpur site and average recorded was $512.67 \pm 126.12$ (Table 1). At Allahabad site, the minimum EC was recorded $375 \mu \mathrm{mho} / \mathrm{cm}$ in the monsoon season, moderately increased in winter season which was $528 \mu \mathrm{mho} / \mathrm{cm}$ and the maximum in summer season as $612 \mu \mathrm{mho} / \mathrm{cm}$. At Allahabad site, the average EC was recorded $505.00 \pm 120.16 \mu \mathrm{mho} / \mathrm{cm}$. At Varanasi site, the average EC was recorded $674.33 \pm 29.94 \mu \mathrm{mho} / \mathrm{cm}$ (Table 3). Gupta [34] reported EC values between 990 to $1285 \mathrm{mg} / \mathrm{l}$ in Yamuna river at Agra which are much higher than those of the present study. High EC values are indicating the presence of higher amount of dissolved inorganic substances in ionized form. Chandra [39] reported $222 \mathrm{mg} / \mathrm{l}$ from the Ganga river at Kasi and $215 \mathrm{mg} / \mathrm{l}$ in Gomti River at Lucknow which was lower as compared to present study.

\section{Sulphates $\left(\mathrm{SO}_{4}^{--}\right)$}

At Kanpur site, the average $\mathrm{SO}_{4}$ recorded was $69.00 \pm 30.51 \mathrm{mg} / \mathrm{l}$, $50.67 \pm 15.53 \mathrm{mg} / \mathrm{l}$ and $45.33 \pm 10.69 \mathrm{mg} / \mathrm{l}$ at Kanpur, Allahabad and Varanasi sites, respectively. At Kanpur site, the minimum $\mathrm{SO}_{4}$ was recorded $48 \mathrm{mg} / \mathrm{l}$ in the winter season, moderately increased $55 \mathrm{mg} / \mathrm{l}$ in summer season with the maximum in the monsoon season as $104 \mathrm{mg} / \mathrm{l}$ (Table 1). The slightly lower concentration of sulphate was recorded at Allahabad site compared to Kanpur site. At Allahabad site, the minimum $\mathrm{SO}_{4}$ was recorded $38 \mathrm{mg} / \mathrm{l}$ in the winter season, moderately increased in summer season which was $46 \mathrm{mg} / \mathrm{l}$ and the maximum in monsoon season $68 \mathrm{mg} / \mathrm{l}$ (Table 2). The minimum $\mathrm{SO}_{4}$ was recorded $36 \mathrm{mg} / \mathrm{l}$ in the winter season, moderately increased in summer season which was $43 \mathrm{mg} / \mathrm{l}$ and the maximum in monsoon season as $57 \mathrm{mg} / \mathrm{l}$ (Table 3).
Chavan [40] observed minimum sulphate $5.34 \mathrm{mg} / \mathrm{l}$ at winter, whereas maximum value $13.95 \mathrm{mg} / \mathrm{l}$ in monsoon season in which both season have lower value compared to present work. Discharge of industrial wastes and domestic sewage in water ends to increase its concentration. Sulphate present in fertilisers they contributes to water pollution and increase sulphate concentration in water bodies. They also come from the runoff water which contain relatively large quantitative of organic and minerals sulphate compound.

\section{Phosphates $\left(\mathrm{PO}_{4}^{-}\right)$}

Phosphates control the algal growth and primary productivity. In most natural water excess amount of phosphorus can cause eutrophication leading to excessive algal growth called algal blooms. At Kanpur site, the average $\mathrm{PO}_{4}$ recorded was $1.02 \pm 0.49 \mathrm{mg} / \mathrm{l}$ in the year 2011-2012. The maximum $\mathrm{PO}_{4}$ was noted $1.58 \mathrm{mg} / \mathrm{l}$ in summer season while as the minimum in the monsoon season $0.66 \mathrm{mg} / \mathrm{l}$ with the moderately increased $0.82 \mathrm{mg} / \mathrm{l}$ in winter season. At Allahabad site, the minimum $\mathrm{PO}_{4}$ was recorded $0.63 \mathrm{mg} / \mathrm{l}$ in the monsoon season, moderately increased in winter season which was $0.78 \mathrm{mg} / \mathrm{l}$ and the maximum in summer season as $1.5 \mathrm{mg} / \mathrm{l}$. The average $\mathrm{PO}_{4}$ was recorded $0.97 \pm 0.47$ and $0.98 \pm 0.46 \mathrm{mg} / \mathrm{l}$ in the year 2011-2012 (Table 2). At Varanasi site, the average $\mathrm{PO}_{4}$ was recorded $1.30 \pm 0.17 \mathrm{mg} / \mathrm{l}$. The minimum $\mathrm{PO}_{4}$ was recorded $1.11 \mathrm{mg} / \mathrm{l}$ in monsoon season, moderately increased in winter season which was $1.37 \mathrm{mg} / \mathrm{l}$ and the maximum in summer season $1.42 \mathrm{mg} / \mathrm{l}$. Singh [27] reported that the $\mathrm{PO}_{4}$ was ranged from $1.01 \pm 0.3$ to $1.58 \pm 0.7 \mathrm{mg} / \mathrm{l}$ at Rajghat (Varanasi).

\section{Alkalinity}

At Kanpur site, the average alkalinity recorded was $189.67 \pm 70.81$ $\mathrm{mg} / \mathrm{l}$. The minimum alkalinity was recorded $123 \mathrm{mg} / \mathrm{l}$ in the summer season while as maximum $264 \mathrm{mg} / \mathrm{l}$ in winter with the moderately increased $182 \mathrm{mg} / \mathrm{l}$ in monsoon season (Table 1). At Allahabad site, the minimum alkalinity was recorded $120 \mathrm{mg} / \mathrm{l}$ in the summer season, moderately increased in monsoon season which was $178 \mathrm{mg} / \mathrm{l}$ and maximum in winter season as $261 \mathrm{mg} / \mathrm{l}$ in year 2011-2012. At Allahabad site, the average alkalinity was recorded $186.3 \pm 70.87 \mathrm{mg} / \mathrm{l}$. At Varanasi site, the average alkalinity was recorded $139.33 \pm 32.50$ $\mathrm{mg} / \mathrm{l}$ in the year 2011-2012. The minimum alkalinity was recorded $107 \mathrm{mg} / \mathrm{l}$ in summer season, moderately increased in monsoon season which was $139 \mathrm{mg} / \mathrm{l}$ and maximum in winter season as $172 \mathrm{mg} / \mathrm{l}$. (Table 3). Praveen [23] reported that alkalinity value was ranged from 12.7 to $245 \mathrm{mg} / \mathrm{l}$ at Kanpur and Thareja [28] observed that the alkalinity was ranged from 108 to $260 \mathrm{mg} / \mathrm{l}$ at same site in 2008-2009. Maheshwari [36] recorded alkalinity values varied from 156 to $210 \mathrm{mg} / \mathrm{l}$ in summer season in the Yamuna River at Agra. The alkalinity of the river water was more in winter when the temperature was lower compared to monsoon and summer seasons.

\section{Chloride $(\mathrm{Cl})$}

The chloride concentration was varied from 15 to 32, 20 to 33 and 43 to $49 \mathrm{mg} / \mathrm{l}$ at Kanpur, Allahabad and Varanasi sites, respectively (Tables 1-3). The average $\mathrm{Cl}$ was recorded $24.6 \pm 8.74$ at Kanpur, 26.6 \pm 6.51 at Allahabad and $45.67 \pm 3.06 \mathrm{mg} / \mathrm{l}$ at Varanasi sites. Trivedi [24] recorded that $\mathrm{Cl}$ value was ranged from $8-30 \mathrm{mg} / \mathrm{l}$ in years 2009 at Kanpur. Gupta [34] reported Cl concentration varied from 180 to 218 $\mathrm{mg} / \mathrm{l}$ in Yamuna River at Agra.

\section{Total Hardness (TH)}

At Kanpur site, the average TH was recorded $174.67 \pm 65$ in the year 2011-2012. The minimum TH was recorded in the monsoon 
Citation: Tiwari A, Dwivedi AC, Mayank P (2016) Time Scale Changes in the Water Quality of the Ganga River, India and Estimation of Suitability for Exotic and Hardy Fishes. Hydrol Current Res 7: 254. doi:10.4172/2157-7587.1000254

Page 5 of 8

season $110 \mathrm{mg} / \mathrm{l}$ while as maximum in winter season $240 \mathrm{mg} / \mathrm{l}$ (Table 1). At Allahabad site, the minimum TH was recorded $107 \mathrm{mg} / \mathrm{l}$ in the monsoon season, moderately increased in summer season which was $170 \mathrm{mg} / \mathrm{l}$ and the maximum in winter season as $235 \mathrm{mg} / \mathrm{l}$. At Allahabad site, the average $\mathrm{TH}$ was recorded $170.67 \pm 64$ (Table 2). At Varanasi site, the average TH was recorded $146.67 \pm 59.03$ in the year 2011-2012 (Table 3). The minimum TH $95 \mathrm{mg} / \mathrm{l}$ was recorded in the monsoon season and moderately increased in summer season which was 134 $\mathrm{mg} / \mathrm{l}$. The maximum $\mathrm{TH}$ was noted in winter season as $211 \mathrm{mg} / \mathrm{l}$ in year 2011-2012 (Table 3). Trivedi [24] observed that the TH was from 108 to $246 \mathrm{mg} / \mathrm{l}$ at Kanpur. Gupta [34] reported TH values ranged from 252 to $304 \mathrm{mg} / \mathrm{l}$ in the Yamuna River at Agra. Water hardness refers to the concentration of divalent calcium, Magnesium, Strontium, Ferrous, and Manganese ions. It is derived largely from soil and rock erosion.

\section{Nitrates $\left(\mathrm{NO}_{3}{ }^{-}\right)$}

At Kanpur site, the average Nitrate was recorded $1.03 \pm 0 \mathrm{mg} / \mathrm{l}$. The minimum Nitrate was recorded in monsoon season $0.45 \mathrm{mg} / \mathrm{l}$, while as maximum in summer season $1.7 \mathrm{mg} / \mathrm{l}$ with the moderately increased $0.94 \mathrm{mg} / \mathrm{l}$ in winter season of year 2011-2012 (Table 1). At Allahabad site, the minimum Nitrate was recorded $0.23 \mathrm{mg} / \mathrm{l}$ in the winter season, moderately increased in monsoon season which was 1.4 $\mathrm{mg} / \mathrm{l}$ and the maximum in summer season as $1.5 \mathrm{mg} / \mathrm{l}$ in year 20112012. At Allahabad site, the average Nitrate was recorded $1.04 \pm 0.71$ in the year 2011-2012 (Table 2). At Varanasi site, the average Nitrate was recorded $2.37 \pm 0.25$ in the year 2011-2012. The minimum Nitrate was recorded $2.1 \mathrm{mg} / \mathrm{l}$ in the winter season and moderately increased in

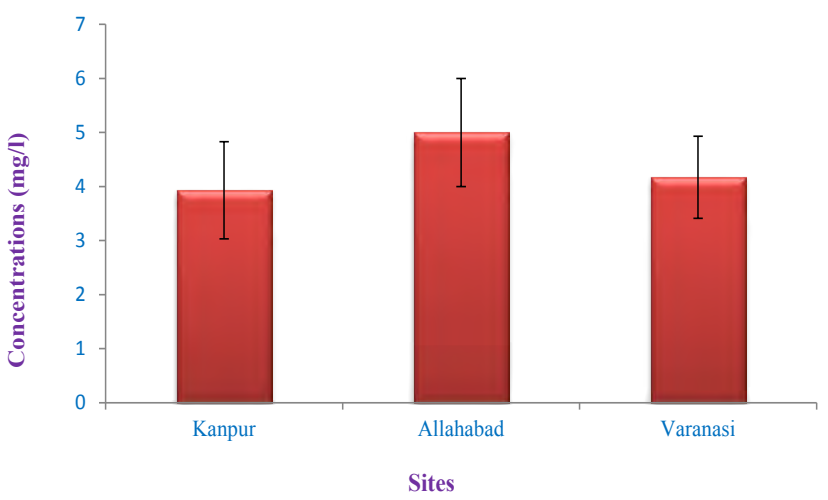

Figure 3: Site variation in DO from the Ganga River, India.

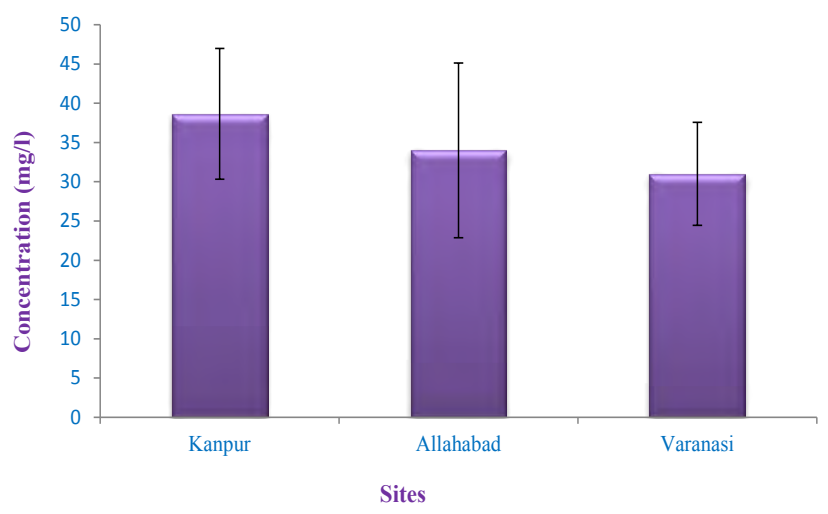

Figure 4: Site variation in BOD from the Ganga River, India. monsoon season which was $2.4 \mathrm{mg} / \mathrm{l}$. The maximum Nitrate was noted in summer season as $2.6 \mathrm{mg} / \mathrm{l}$ in year 2011-2012 (Table 3). Tripathi [31] reported mean value of $\mathrm{NO}_{3}$ was $1.10 \pm 0.40 \mathrm{mg} / \mathrm{l}$ at Varanasi, Rai [32] observed $\mathrm{NO}_{3}$ ranged $0.85 \pm 0.31 \mathrm{mg} / \mathrm{l}$ to $1.30 \pm 0.22 \mathrm{mg} / \mathrm{l}$ in the year (2005), at Rajghat (Varanasi) in the river Ganga. In surface waters nitrogen may exist as particulates or dissolved forms. Organic nitrogen decays to produce ammonia via anaerobic bacteria decayed process. Ammonia in turn converted to nitrites and ultimate to nitrates via the process of nitrification, an aerobic bacteria procedure. Algae readily take up dissolved inorganic nitrogen, which consist of ammonia and nitrate with a typical preference for ammonia. Nitrates added into the river water mainly by agricultural runoff.

\section{Dissolved Oxygen (DO)}

At Kanpur site, the average DO was recorded $3.93 \pm 0.90 \mathrm{mg} / \mathrm{l}$ in the year 2011-2012. The minimum DO was recorded in the monsoon season $3.0 \mathrm{mg} / \mathrm{l}$ while as maximum in winter $4.8 \mathrm{mg} / \mathrm{l}$ with the moderately increased $4 \mathrm{mg} / \mathrm{l}$ in summer season of year 2011-2012 (Table 1). At Allahabad site, the minimum DO was recorded $4 \mathrm{mg} / \mathrm{l}$ in the monsoon season, moderately increased in summer season which was $5 \mathrm{mg} / \mathrm{l}$ and the maximum in winter season as $6 \mathrm{mg} / \mathrm{l}$ in year 2011-2012. At Allahabad site, the average DO was recorded $5.00 \pm 1$ in the year 20112012 (Table 2). At Varanasi site, the average DO was recorded $4.17 \pm$ 0.76 in the year 2011-2012 (Figure 3). The minimum DO was recorded $3.3 \mathrm{mg} / \mathrm{l}$ in the monsoon season, moderately increased in summer season $4 \mathrm{mg} / \mathrm{l}$ and the maximum DO in winter season $5 \mathrm{mg} / \mathrm{l}$ in year 2011-2012 (Table 3). Tripathi [31] recorded mean value of DO was 0.90 $\pm 0.50 \mathrm{mg} / \mathrm{l}$ at Varanasi. Maheshwari [36] reported DO varied from 5.5 to $8.2 \mathrm{mg} / \mathrm{l}$ in summer from Yamuna river at Agra. According to USPH standard, DO values should range from 4.0 to $6.0 \mathrm{mg} / \mathrm{l}$ for fishes. Value of DO increased in winter due to circulation of cold water as well as high solubility of oxygen at low temperature. DO play an important role in water quality determination. The introduction of oxygen demanding materials, either organic or inorganic, in to water causes depletion of the dissolved oxygen in the water. This poses a threat to fish and other higher forms of aquatic life if the concentration of oxygen falls below critical point. But in case of C. carpio, O. niloticus and catfishes, even low concentration of oxygen are acceptable for growth and production in water [41]. Due to low concentration of oxygen in the river Ganga other fishes (especially carps) are suffer for survival and growth. DO levels in surface water body indicate the ability to support aquatic life. The high DO values means the rate of oxygen replenishment in water is greater than the oxygen utilization. Adequate DO is necessary for good water quality. DO levels between 5.0 and $8.0 \mathrm{mg} / \mathrm{l}$ are satisfactory for survival and growth of aquatic organisms. The concentrations of DO in surface waters are affected by water temperature. Colder water can hold more DO than warmer water and saturation occurs at higher concentrations in winter. DO may decrease in north temperature ecosystem.

\section{Biochemical Oxygen Demand (BOD)}

At Kanpur site, the average BOD was recorded $38.67 \pm 8$ (Figure 4 ). The minimum BOD was recorded in the winter season $32 \mathrm{mg} / \mathrm{l}$ while as maximum $48 \mathrm{mg} / \mathrm{l}$ in monsoon of year 2011-2012 (Table 1). At Allahabad site, the average BOD was recorded $34.00 \pm 11.14$ in the year 2011-2012. The minimum BOD $22 \mathrm{mg} / \mathrm{l}$ was recorded in the winter season, moderately increased in summer season which was $36 \mathrm{mg} / \mathrm{l}$, and the maximum BOD was noted in monsoon season as $44 \mathrm{mg} / \mathrm{l}$ in year 2011-2012 (Table 2). At Varanasi site, the average BOD was recorded $31.00 \pm 6.56$ in the year 2011-2012. The minimum BOD was recorded $25 \mathrm{mg} / \mathrm{l}$ in the winter season, moderately increased in summer season 
Citation: Tiwari A, Dwivedi AC, Mayank P (2016) Time Scale Changes in the Water Quality of the Ganga River, India and Estimation of Suitability for Exotic and Hardy Fishes. Hydrol Current Res 7: 254. doi:10.4172/2157-7587.1000254

Page 6 of 8

which was $30 \mathrm{mg} / \mathrm{l}$ and maximum in monsoon season as $38 \mathrm{mg} / \mathrm{l}$ in year 2011-2012 (Table 3). Singh [27] observed that the BOD was ranged from $66.2 \pm 3.4$ to $87.5 \pm 2.9 \mathrm{mg} / \mathrm{l}$ at Rajghat (Varanasi) while Rai [32] reported BOD range was from $97 \pm 41$ to $265 \pm 78 \mathrm{mg} / \mathrm{l}$ in the year 2005 at the same site, Chandra [39], Chavan et al. reports minimum BOD $1.38 \mathrm{mg} / \mathrm{l}$ during winter and maximum value $6.51 \mathrm{mg} / \mathrm{l}$ in monsoon season. Chavan [40] records values of $3.9 \mathrm{mg} / \mathrm{l}$ BOD at Ganga Kasi, and $2.1 \mathrm{mg} / \mathrm{l}$ at Lucknow in Gomti River. Khwaja [37] provides mean BOD value $2.8 \pm 0.4$ in summer and $3.5 \pm 0.4 \mathrm{mg} / \mathrm{l}$ in winter at Kanpur from the Ganga River. Katiyar [38] reports very higher BOD mean 41.7 $\pm 1.26 \mathrm{mg} / \mathrm{l}$ during summer, $34.12 \pm 1.57 \mathrm{mg} / \mathrm{l}$ during monsoon, 36.69 $\pm 1.40 \mathrm{mg} / \mathrm{l}$ during winter at Jajmau, Kanpur compared to the present investigation. Due to higher values of BOD in the river Ganga are suitable for C. carpio, O. niloticus and catfishes (due to hardy nature) for growth and production while other fishes are suffer for survival and growth. BOD is the amount of oxygen required by the living organisms (microbes) in the utilization or stabilization of organic matter in water over a 5 day period. It is very important indicator of the organic pollution status of a water body. The unpolluted water has BOD values of $3 \mathrm{mg} / \mathrm{l}$ or less and industrial waste waters have BOD values 25000 $\mathrm{mg} / \mathrm{l}$. BOD values generally approximates the amount of oxidisable organic matter, and is therefore, used as a measure of degree of water pollution and waste level. BOD values are thus use full in evaluation of self-purification capacity of a water body and for possible control measure of pollution.

\section{Chemical Oxygen Demand (COD)}

COD is a method to determine the organic load of water body i.e., susceptible to oxidation. COD as a result of pollution is largely determined by the various organic and inorganic materials as like calcium, magnesium, potassium, sodium etc. The levels of COD seem to be the appropriate indices for assessing the pollution level of water bodies. The high COD values are found mainly in water, which may be due to the mixing of domestic and industrial wastes. At Kanpur site, the average COD was recorded $29.67 \pm 8.02 \mathrm{mg} / \mathrm{l}$. The minimum COD was recorded in the summer season $22 \mathrm{mg} / \mathrm{l}$ while as maximum in monsoon $38 \mathrm{mg} / \mathrm{l}$ with the moderately increased $29 \mathrm{mg} / \mathrm{l}$ in winter season of year 2011-2012 (Table 1). At Allahabad site, the minimum COD $19 \mathrm{mg} / \mathrm{l}$ was recorded in the summer season, moderately increased in winter season $23 \mathrm{mg} / \mathrm{l}$ and the maximum in monsoon season as $28 \mathrm{mg} / \mathrm{l}$ in year 2011-2012. At Allahabad site, the average COD was recorded $23.33 \pm 4.51 \mathrm{mg} / \mathrm{l}$ in the year 2011-2012 (Table 2). At Varanasi site, the average COD was recorded $27.67 \pm 7.64$ in the year 2011-2012 (Figure 5). The minimum COD were recorded $21 \mathrm{mg} / \mathrm{l}$ in the summer season,

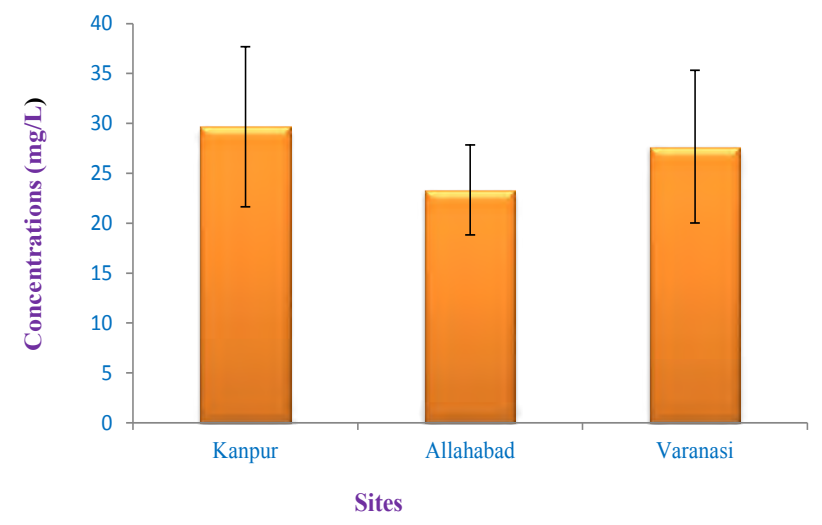

Figure 5: Site variation in COD from the Ganga River, India.

\begin{tabular}{|c|c|c|c|c|c|c|}
\hline \multirow{2}{*}{ Fishes/groups } & \multirow{2}{*}{ Water bodies } & \multicolumn{4}{|c|}{ Relative abundance (according to number) } \\
\cline { 3 - 6 } & & Kanpur & Allahabad & Varanasi & Source \\
\hline Major carps & Ganga river & 13.13 & 9.64 & 10.71 & {$[13]$} \\
\hline $\begin{array}{c}\text { Catfishes (Hardy } \\
\text { fishes) }\end{array}$ & Ganga river & 63.44 & 72.04 & 70.47 & {$[13]$} \\
\hline Cyprinus carpio & Ganga river & 10.25 & 8.75 & 9.64 & {$[13]$} \\
\hline Oreochromis niloticus & Ganga river & 13.18 & 9.66 & 9.18 & {$[13]$} \\
\hline & & Landing scenario (according to weight) \\
\hline Major carps & Ganga river & & 8.74 & {$[15]$} \\
\hline Catfishes (Hardy fishes) & Ganga river & & 40.67 & & {$[15]$} \\
\hline Cyprinus carpio & Ganga river & & 14.20 & & {$[15]$} \\
\hline Oreochromis niloticus & Ganga river & & 12.54 & & {$[15]$} \\
\hline Major carps & Yamuna river & & 12.97 & & {$[18]$} \\
\hline Catfishes (Hardy fishes) & Yamuna river & & 25.32 & & {$[18]$} \\
\hline Cyprinus carpio & Yamuna river & & 21.76 & & {$[18]$} \\
\hline Oreochromis niloticus & Yamuna river & & 24.36 & & {$[18]$} \\
\hline Major carps & Yamuna river & & 8.00 & & {$[15]$} \\
\hline Catfishes (Hardy fishes) & Yamuna river & & 23.98 & & {$[15]$} \\
\hline Cyprinus carpio & Yamuna river & & 25.18 & & {$[15]$} \\
\hline Oreochromis niloticus & Yamuna river & & 19.07 & & {$[15]$} \\
\hline Cyprinus carpio & Ken river & & 17.80 & {$[17]$} \\
\hline Cyprinus carpio & Paisuni river & & 6.43 & {$[17]$} \\
\hline Cyprinus carpio & Tons river & & 4.06 & {$[17]$} \\
\hline
\end{tabular}

Table 4: Relative abundance and landing scenario of fishes and groups from the various rivers, India (\%).

moderately increased in winter season $26 \mathrm{mg} / \mathrm{l}$ and the maximum in monsoon season as $36 \mathrm{mg} / \mathrm{l}$ in year 2011-2012 (Table 3). Tripathi [31] recorded higher mean values of COD $520 \pm 180 \mathrm{mg} / \mathrm{l}$ at Varanasi compared to present findings. Chandra [39] reported $22 \mathrm{mg} / \mathrm{l}$ at Ganga Kasi and $14 \mathrm{mg} / \mathrm{l}$ at Lucknow from the Gomti River, lower compared to present observation.

The chemical oxygen demand is commonly used to determine the amount of organic pollutants found in surface waters. COD is a measure of the oxygen equivalent of the organic matter in a water sample that is susceptible to oxidation by a strong chemical oxidant, such as dichromate [42]. Oxygen demand value is useful in specifying toxic condition and presence of biological resistant substances. BOD and COD are usually at or near analytical limits of detection in relatively undisturbed systems. Khwaja [37] estimated lower mean values of COD compared to present findings $14 \pm 0.8$ in summer and $19.7 \pm 0.9 \mathrm{mg} / \mathrm{l}$ in winter at Kanpur from the Ganga River. Heavy metals accumulation was reported higher in the gills from the Ganga river but gill rakers and gill lamellae found safe conditions in case of $C$. carpio and O. niloticus [43].

The poor water quality of the Ganga river was most suitable for catfishes (hardy fishes), C. carpio and O. niloticus at Kanpur, Allahabad and Varanasi sites. The Indian riverine sector (specially central India) presently dense by $C$. carpio and O. niloticus (Table 4) due to poor water quality. Table 4 is shows that the C. carpio and O. niloticus highly landed (shared in landing) in earlier in the Ganga, Yamuna, Ken, Paisuni and Tons rivers which is reported by Ref. [13,15,17,18]. Present dense condition of $C$. carpio and $O$. niloticus were also reported by Mayank [44], Dwivedi [45] from the Vindhyan region and Yamuna river.

It may be concluded that the water quality of the Ganga river contaminated by the ample pollutants at Kanpur, Allahabad and Varanasi sites. It may be also concluded that the water of the Ganga River most suitable for C. carpio and O. niloticus by earlier reports (landing and relative abundance). Due to higher values of BOD and 
Citation: Tiwari A, Dwivedi AC, Mayank P (2016) Time Scale Changes in the Water Quality of the Ganga River, India and Estimation of Suitability for Exotic and Hardy Fishes. Hydrol Current Res 7: 254. doi:10.4172/2157-7587.1000254

COD in the river Ganga are suitable for C. carpio, O. niloticus and catfishes for growth and production while other fishes are suffer for survival and growth.

\section{References}

1. Canli M, Ay O, Kalay M (1998) Level of heavy metals (Cd, $\mathrm{Pb}, \mathrm{Cu}$ and $\mathrm{Ni}$ ) in tissues of Cyprinus carpio, Barbus capito and Chondrostoma regium from the Seyhan River Turkey. Journal of Zoology 22: 149-157.

2. Voegborlo RB, El-Methnani AM, Abedin MZ (1999) Mercury, cadmium and lead content of canned tuna fish. Food Chemistry 67: 341-345.

3. Dirilgen N (2001) Accumulation of heavy metals in freshwater: Assessment of toxic interactions. Turkey Journal of Chemistry 25: 173-179.

4. Vutukuru SS (2005) Acute effects of Hexavalent chromium on survival, oxygen consumption, hematological parameters and some biochemical profiles of the Indian Major carp, Labeo rohita. International Journal of Environmental Research and Public Health 2: 456- 462

5. Dwivedi AC, Tiwari A, Mayank P (2015) Seasonal determination of heavy metals in muscle, gill and liver tissues of Nile tilapia, Oreochromis niloticus (Linnaeus, 1758) from the tributary of the Ganga River, India. Zoology and Ecology 25: 166-171.

6. Yang Y, Yun X, Liu M, Jian Y, Li QX, Wang J (2014) Concentrations, distributions, sources, and risk assessment of organochlorine pesticides in surface water of the East lake, China. Environmental Science and Pollution Research 21: 3041 3050.

7. Tiwari A, Kushwaha AS, Dwivedi AC (2015) Accumulation of heavy metals in liver, muscle and gill of Cyprinus carpio from the Ganga River at Varanasi, Uttar Pradesh. Journal of the Kalash Science 3: 47-51.

8. Ajima MNO, Nnodi PC, Ogo OA, Adaka GS, Osuigwe DI, et al. (2015) Bioaccumulation of heavy metals in Mbaa river and the impact on aquatic ecosystem. Environmental Monitoring and Assessment

9. Heath AG (1987) Water Pollution and Fish Physiology. CRC press 245. Florida, USA.

10. Suziki KT, Sunaga H, Aoki Y, Hatakeyama S, Sumi Y, et al. (1988) Binding of cadmium and copper in the mayfly Baetis thermicus larvae that inhabit in a river polluted with heavy metals. Comparative Biochemistry and Physiology 91C: $487-492$

11. Allen $P$ (1995) Accumulation profiles of lead and cadmium in the edible tissues of Oreochromis aureus during acute exposure. Journal of Fish Biology 47: 559568.

12. Tiwari A, Dwivedi AC (2014) Assessment of heavy metals bioaccumulation in alien fish species Cyprinus carpio from the Gomti River, India. European Journal of Experimental Biology 4: 112-117.

13. Dwivedi AC, Mishra AS, Mayank P, Tiwari A (2016) Persistence and structure of the fish assemblage from the Ganga River (Kanpur to Varanasi section), India. Journal of Geography and Natural Disasters 6: 159.

14. Altug G, Balkis N (2009) Levels of some toxic elements and frequency of bacterial heavy metal resistance in sediment and sea water. Environment Monitoring and Assessment 149: 61-66.

15. Pathak RK, Gopesh A, Dwivedi AC (2015) Invasion potential and biology of Cyprinus carpio (Common carp). LAP LAMBERT Academic Publishing $\mathrm{GmbH}$ \& Co. KG, Dudweiler Landstr. 99, 66123 Saarbrucken, Germany.

16. Dwivedi AC, Mayank P (2013) Studies on the age, growth pattern and sex ratio of Cyprinus carpio var. communis from the largest tributary of the Ganga river, India. Journal of the Kalash Science, Special Volume: 21-27.

17. Dwivedi AC, Nautiyal P (2013) Alien fish species, Cyprinus carpio (common carp) as a invader in the Vindhyan region (Ken, Paisuni, Tons rivers), India. Journal of the Kalash Science 1: 133-139.

18. Mayank P, Dwivedi A C (2015) Role of exotic carp, Cyprinus carpio and Oreochromis niloticus from the lower stretch of the Yamuna River. Advances in biosciences and Technology edited by Pandeya KB, Mishra AS, Ojha RP, Singh AK. Published by NGBU, Allahabad, pp: 93-97

19. Mayank P, Dwivedi AC (2015) Biology of Cirrhinus mrigala and Oreochromis niloticus. LAP LAMBERT Academic Publishing $\mathrm{GmbH}$ \& Co. KG, Dudweiler Landstr. 99, 66123 Saarbrucken, Germany, p: 188.
20. Pathak RK, Gopesh A, Dwivedi AC (2011) Alien fish species, Cyprinus carpio var. communis (common carp) as a powerful invader in the Yamuna river at Allahabad, India. National Academy of Science Letter 34: 367-373.

21. Dwivedi AC, Nautiyal P, Rizvi AF, Mayank P (2016) Landing scenario, size and age of commercially important fish species, Labeo rohita, Tor tor and L. calbasu response to need their restoration in the Vindhyan region (Paisuni river), India. Journal of the Kalash Science 4: 27-40.

22. APHA (1998) Standard methods for the examination of water and wastewater 20th edn. Amer. Pub. H. Associ., New York, USA.

23. Praveen A, Kumar R, Pratima, Kumar R (2013) Physico-chemical properties of the water of river Ganga at Kanpur. International Journal Computational Engineering Research 3: 134-137.

24. Trivedi $P$, Bajpai $A$, Thareja S (2010) Comparative study of seasonal variation in physico-chemical characteristics in drinking water quality of Kanpur, India with reference to 200 MLD filtration plant and ground water. Nature and Science 8: $11-17$

25. Raghuvanshi D, Singh H, Pandey R, Tripathi B, Shukla DN (2014) Physicochemical properties and correlation co-efficient of river Ganga at Allahabad. Bulletin of Environment, Pharmacology and Life Science 3: 233-240.

26. Zafer A, Sultana N (2007) Seasonal analysis in the water quality of river Ganga disaster ecology and environment. Arvind K (eds.), Daya publishing house, India, pp: 57-62.

27. Singh N (2010) Physico-chemical properties of polluted water of river Ganga at Varanasi. International Journal of Energy and Environment 1: 823-832.

28. Thareja S, Choudhury S, Trivedi $P$ (2011) Assessment of water quality of Ganga River in Kanpur by using principal components analysis. Advances Applied Science Research 2: 84-91.

29. Esmaeili HR, Johal MS (2005) Study of physico-chemical parameters of water of Gobindsagar reservoir, India. In: Johal MS (eds.), Proceedings of the National Seminar "New Trends in Fishery Development in India". Punjab University, Chandigarh, Feb. 16-16: 173-177.

30. Singh RP, Mathur P (2005) Investigation of variations in physico-chemical characteristics of a fresh water reservoir of Ajmer city, Rajasthan. International Journal of Environmental Science 9: 57-61.

31. Tripathi BD, Sikandar M, Shukla SC (1991) Physico-chemical characterization of city sewage discharged into river Ganga at Varanasi, India. Environmental International 17: 469-478.

32. Rai PK, Mishra A, Tripathi BD (2010) Heavy metal and microbial pollution of the river Ganga: a case study of water quality at Varanasi. Aquatic Ecosystem and Health Management 13: 352-361.

33. Kar D, Surr P, Mandal SK, Saha T, Kole RK (2008) Assessment of heavy meta pollution in surface water. International Journal of Environmental Science and Technology 5: 119-124.

34. Gupta N, Yadav KVK, Singh D (2013) Assessment of physicochemical properties of Yamuna river in Agra city. International Journal of ChemTech Research 5: 528-531.

35. Vilizzi L, Tarkan AS, Copp GH (2015) Experimental evidence from causal criteria analysis for the effects of Common carp Cyprinus carpio on freshwater ecosystems: A global perspective. Reviews in Fisheries Science \& Aquaculture 23: $253-290$.

36. Maheshwari A, Sharma M, Sharma D (2011) Hydro Chemical analysis of surface and ground water quality of Yamuna River at Agra, India. Journal of materials and Environmental Science 2: 373-378.

37. Khwaja AR, Singh R, Tandon SN (2001) Monitoring of Ganga water and sediment tannery pollution at Kanpur (India): A Case Study. Environmental Monitoring and Assessment 68: 19-35.

38. Katiyar S (2011) Impact of tannery effluent with special reference to seasonal variation on physico-chemical characteristics of river water at Kanpur (U.P) India. Journal of Environmental Analysis Toxicology 1: 4.

39. Chandra S, Singh A, Tomar PK, Kumar A (2011) Evaluation of Physicochemical Characteristics of Various river water in India. E Journal of Chem 8: 1546-1555.

40. Chavan AW, Dhamani AA, Murkute VB (2006) Seasonal variation in the physicochemical parameter of river Wainanga near Bramhapuri, Dist Chandrapur. Vidh. Inter. Interd. Res. J 1: 28-35. 
Citation: Tiwari A, Dwivedi AC, Mayank P (2016) Time Scale Changes in the Water Quality of the Ganga River, India and Estimation of Suitability for Exotic and Hardy Fishes. Hydrol Current Res 7: 254. doi:10.4172/2157-7587.1000254

Page 8 of 8

41. Dwivedi AC, Tewari NP, Singh KR (2004) Present structure of capture and culture fishery of the Faizabad District (U.P.). Bioved 15: 95-98.

42. Chapman PM, Allen HE, Godtfredsen K, Graggen MN (1996) Evaluation of bioaccumulation factors in regulating metals. Environmental Science Echnol 30: $448-452$

43. Tiwari A, Dwivedi AC, Shukla DN, Mayank P (2014) Assessment of heavy metals in different organ of Oreochromis niloticus from the Gomti river at
Sultanpur, India. Journal of the Kalash Science 2: 47-52

44. Mayank P, Dwivedi AC (2015) Population structure of alien fish species, Oreochromis niloticus (Linnaeus 1758) from lower stretch of the Yamuna river India. Journal of the Kalash Science 3: 35-40.

45. Dwivedi AC, Nautiyal P (2010) Population dynamics of important fishes in the Vindhyan region, India. LAP LAMBERT Academic Publishing GmbH \& Co. KG, Dudweiler Landstr. 99, 66123 Saarbrucken, Germany, p: 220. 